\title{
Effect of potassium-based emulsifying salts on sensory, textural, and functional attributes of low-sodium processed Mozzarella cheese
}

\author{
Ganesh B. Chavhan • S. K. Kanawjia • \\ Yogesh Khetra $\cdot$ Ritika Puri
}

Received: 25 July 2014 / Revised: 16 November 2014 / Accepted: 17 November 2014 / Published online: 18 December 2014

C INRA and Springer-Verlag France 2014

\begin{abstract}
Dietary sodium content is considered as a major contributor to hypertension and cardiovascular diseases. Mozzarella cheese contains high amount of sodium, and addition of emulsifying salts (ESs) to the manufacture of processed cheese further adds to the overall sodium content. The present investigation envisaged the manufacture of low-sodium processed Mozzarella cheese by partial replacement of sodium chloride with potassium chloride $(\mathrm{KCl})$ and also by using potassium-based emulsifying salts, i.e., potassium citrate and di-potassium phosphate, in place of sodium-containing salts. Desired level of potassium chloride and potassium-based emulsifying salt was optimized using response surface methodology (RSM). Sensory attributes, instrumental hardness, meltability, and stretchability were kept as responses of the design. The study returned $30.96 \%$ of $\mathrm{KCl}$ and $2 \%$ of emulsifying salt to be optimum, and at these levels, the product had maximum sensory scores. Hardness, meltability, and stretchability of the product were reported to be $14.355 \mathrm{~N}, 21.68 \mathrm{~cm}$ and $15.07 \mathrm{~cm}$, respectively. Further, the study was validated by manufacturing the product using optimized levels of ESs and $\mathrm{KCl}$ and comparing the actual responses with the responses predicted by RSM. No significant difference $(p>0.05)$ between actual and predicted values validated the results of RSM. Full-sodium and low-sodium cheeses had $905 \mathrm{mg} / 100 \mathrm{~g}$ and $260 \mathrm{mg} / 100 \mathrm{~g}$ sodium, respectively. Thus, the study resulted in $71.27 \%$ reduction in overall sodium content of processed Mozzarella cheese.
\end{abstract}

\footnotetext{
G. B. Chavhan $\cdot$ S. K. Kanawjia $\cdot$ Y. Khetra $(\bowtie) \cdot$ R. Puri

Dairy Technology, National Dairy Research Insititute, Karnal, Haryana 132001, India

e-mail: yogesh.khetra@gmail.com

G. B. Chavhan

e-mail: ganeshchavan74@gmail.com

S. K. Kanawjia

e-mail: skkanawjia@rediffmail.com

R. Puri

e-mail: ritika02foodtech@gmail.com
} 
Keywords Emulsifying salts · Potassium chloride $\cdot$ Low-sodium Mozzarella cheese $\cdot$ Meltability · Stretchability

\section{Introduction}

Besides providing salty taste, sodium chloride $(\mathrm{NaCl})$ is regarded as a characteristic seasoning agent in foods (Gillette 1985). The recommended maximum daily intake of salt is $5 \mathrm{~g}$ per day which is equivalent to $2 \mathrm{~g}$ of sodium per day (WHO 2012). However, the daily sodium intake in industrialized developed countries is usually about five to six times higher than the maximum recommended daily intake (WHO 2003). Processed foods are an integral part of Western diets which contain approximately three times more sodium than is recommended for daily consumption. High-sodium diet leads to retention of water in the body consequently becoming the cause for hypertension, an important risk factor for the development of cardiovascular diseases (Tuomilehto et al. 2001). Therefore, in recent years, there is emerging trend to reduce sodium in processed foods.

Mozzarella cheese, known for its meltability, stretchability, and shredability, is a semi-soft type of cheese popular in the USA especially in pizza. Processed Mozzarella cheese (PMC) is manufactured by utilizing Mozzarella cheese as raw material followed by heat processing in the presence of emulsifying salts (ESs) such as trisodium citrate and disodium phosphate to prolong the shelf life of Mozzarella cheese. To increase retail market penetration, longer shelf life Mozzarella cheese manufacture has been a growing trend among Indian cheese manufacturers. This has resulted in spurt increase in PMC production in India.

ESs are added in processed cheese to modify milk proteins which causes emulsifying action. In the presence of heat and shear, ESs cause sequestration of calcium present in colloidal calcium phosphate complex and hydration of para-casein (Guinee et al. 2004; Cunha and Viotto 2010). The resultant dispersion of protein results in a casein micelle network that dissolves and break down into particles roughly in the size range of casein sub-micelles. Sequestration of calcium enables the caseins to function as emulsifiers in the water-oil interface (Zehren and Nusbaum 1992). Surfaces of dispersed free fat droplets are coated with dispersed casein attributing to increased emulsification and to immobilization of a large amount of free water due to its hydrated nature (Guinee et al. 2004). Monovalent cations and polyvalent anions are the two basic components of orthophosphate ESs, which are mostly sodium-based and therefore contribute to increased sodium content of processed Mozzarella cheese. Hence, the high-sodium content of processed Mozzarella cheese further increases the sodium content of pizza product.

Exploiting potassium-based emulsifying salts for processing and partial replacements of $\mathrm{NaCl}$ with $\mathrm{KCl}$ in cheese are two main approaches to reduce sodium content of cheese. Efforts have also focused on the blending of potassium-containing emulsifying salts in appropriate ratio with sodium salts without compromising the quality (Johnson et al. 2009). Potassium-based emulsifying salts have been successfully used to reduce the sodium content in other processed cheeses (Gupta et al. 1984; Hoffmann et al. 2012). Upon substitution of sodium emulsifying salts with potassium, the controlled exchange of calcium takes place with potassium. Calcium sequestration and hydration of para-casein caused by exchange of potassium with calcium result in 
functional and sensory properties similar to processed cheese made with sodium-based emulsifying salts (Hoffmann et al. 2012) although these authors included sodium polyphosphate ESs in the ES blend. However, Gupta et al. (1984) evaluated the effects of emulsifying salts on sensory and textural characteristics of processed cheese and concluded that potassium-based emulsifiers may replace sodium-based emulsifiers. However, the study did not include bitterness scores which is the primary restraint in substitution of $\mathrm{NaCl}$ with $\mathrm{KCl}$ in foods. Nevertheless, emulsifying systems, based only on potassium orthophosphates to reduce the concentration of sodium, did not produce cheese with high levels of acceptance (Hoffmann et al. 2012). He also studied the effect of various emulsifying salts containing potassium on the quality of block-type processed cheese and concluded that potassium polyphosphates individually are not suited for emulsification in processed cheese because of their low solubility in water. Potassium chloride $(\mathrm{KCl})$ has been acknowledged as a potential substitute to $\mathrm{NaCl}$. According to Cruz et al. (2011), $\mathrm{KCl}$ helps to replace up to $25 \%$ of $\mathrm{NaCl}$ without losses in palatability and without adversely influencing salty perception. However, this addition of $\mathrm{KCl}$ may attribute to present residual sour flavor that is unacceptable to consumers to some extent (Guinee and O' Kennedy 2007). A mixture of $\mathrm{NaCl}$ and $\mathrm{KCl}$ has been successfully used in Halloumi (Ayyash and Shah 2010) and Kefalograviera cheese (Katsiari et al. 2002) without any adverse effects on cheese quality. The use of $\mathrm{KCl}$ as salt substitute is mainly limited due to the association of non-salty tastes, especially sour taste (Ayyash and Shah 2010). The lower flavor scores of the cheese salted with the $1: 1 \mathrm{NaCl} / \mathrm{KCl}$ mixture due to a slightly burning-metallic aftertaste, typical of KCl, were observed in the study of Katsiari et al. (1998). Similar results were observed by Reddy and Marth (1994) and Aly (1995), in their studies on the effect of partial substitution of $\mathrm{NaCl}$ by $\mathrm{KCl}$ on the flavor of Cheddar and UF Feta type cheese, respectively. However, so far, no information on the effect of potassium-based emulsifying salts and partial substitution of $\mathrm{NaCl}$ with $\mathrm{KCl}$ on $\mathrm{PMC}$ is available.

The present study was conducted to determine the effect of potassium citrate and dipotassium phosphate emulsifying salts and partial replacement of $\mathrm{NaCl}$ with $\mathrm{KCl}$ on the sensory, textural, and functional properties of PMC.

\section{Materials and methods}

Buffalo's fresh milk was procured from the Experimental Dairy, National Dairy Research Institute, Karnal (Haryana), India. Microbial rennet (Meito) commercially produced in granular form from Mucor pusillus var. Lindt was procured from Meito Sangyo Co., Ltd., Tokyo, Japan. Commercial-grade fine $\mathrm{NaCl}$ salt was obtained from $\mathrm{M} / \mathrm{S}$ Tata Chemicals, Bombay. Commercial-grade $\mathrm{KCl}$ was purchased from Polypharma Pvt. Ltd., Mumbai. Potassium citrate was purchased from J K Brothers Ltd., Mumbai, India. Di-potassium Phosphate was purchased from Arti Phosphates Pvt. Ltd., Mumbai, India. All the chemicals and reagents used for analysis were of AR grade.

\subsection{Preparation of Mozzarella cheese}

Mozzarella cheese used in this study was manufactured in Experimental Dairy, National Dairy Research Institute (Karnal, India) using buffalo milk by direct acidification method 
(Jensen et al. 1987) with certain modifications. Buffalo milk was standardized to $4 \%$ fat, pasteurized at $63{ }^{\circ} \mathrm{C} / 30 \mathrm{~min}$, and cooled to $7{ }^{\circ} \mathrm{C}$, and then diluted $\mathrm{HCl}(25 \%)$ was added until $\mathrm{pH}$ drops to 5.4-5.6. Then, temperature of milk was increased up to $25^{\circ} \mathrm{C}$ and rennet (Meito) was added at $1.0 \mathrm{~g} / 100 \mathrm{l}$ of milk. When the curd was properly set, it was cut using $1 / 3$-inch horizontal and vertical cheese knives. Cheese cubes were then cooked in whey until the temperature reached $37^{\circ} \mathrm{C}$. The whey was drained and maturing of curd was started. The curd was cut into smaller pieces at $\mathrm{pH}$ of about 5.2 and stretched/plasticized under hot water $\left(80-85^{\circ} \mathrm{C}\right)$. Quantity of hot water was two times the weight of curd. Plasticized curd was moulded into spherical balls and placed in cold water at $4{ }^{\circ} \mathrm{C}$ for a while. The unsalted Mozzarella cheese was stored at refrigeration temperature of $7 \pm 1{ }^{\circ} \mathrm{C}$ which was further used for manufacture of PMC.

\subsection{Preparation of processed Mozzarella cheese}

Unsalted Mozzarella cheese was taken for preparation of low-sodium PMC. The amount of total salt, i.e., $\mathrm{NaCl}+\mathrm{KCl}$ was kept at $1 \%$ while the ratio of $\mathrm{KCl} / \mathrm{NaCl}$ was varied as per the response surface methodology (RSM) design. Emulsifying salt (ES) used in the study comprised a blend of potassium citrate and di-potassium phosphate (hereafter referred to as emulsifying salt) in the ratio of $1: 1$. The level of ES ranged from 1 to $2 \%(w / w)$. Mozzarella cheese was quartered and added to heating kettle. The contents in the kettle were heated with continuous stirring and scraping. As the temperature approached $50{ }^{\circ} \mathrm{C}$, emulsifying salt, $\mathrm{NaCl}$, and $\mathrm{KCl}$ were added to the kettle. Heating was continued until the temperature reached $75^{\circ} \mathrm{C}$ and held for about 4-5 min followed by transfer to moulds. The product was allowed to cool at room temperature and kept thereafter at refrigeration temperature. The cooled product was further cut into blocks of $250 \mathrm{~g}$ and packed in KPA-Cryovac ${ }^{\circledR}$ packages. The packed product was stored under refrigeration until required. Full-sodium processed Mozzarella cheese was prepared with $1 \% \mathrm{NaCl}$ and $2 \%$ trisodium citrate. This was used as control to determine percent sodium reduction in low-sodium processed Mozzarella cheese.

\subsection{Compositional analysis}

Moisture, ash, salt (ISI 1981), fat, protein (AOAC 1992), and sodium and potassium (AOAC 1990) were determined for full-sodium and optimized products.

\subsection{Sensory evaluation}

The PMC was presented for sensory evaluation to a panel of eight trained judges from Dairy Technology Division of National Dairy Research Institute, Karnal. All the judges were trained sensory analysts with a minimum of 5 years of experience. A descriptive sensory scorecard with 90-point scale was used. The scorecard was developed based on American Dairy Science Association. However, maximum scores for sensory attributes were modified on the basis of recommendation of sensory panel. Maximum scores for flavor; body and texture; and color and appearance were 50,30, and 10, respectively. The samples were presented in random order to eliminate carry over effects. The tests were carried out in individual booths under white light. Judges received approximately 
$20 \mathrm{~g}$ of each sample, served at the refrigeration temperature $\left(7^{\circ} \mathrm{C}\right)$ in disposable plastic cups coded with random three-digit numbers, accompanied by a teaspoon for tasting the pure product.

\subsection{Hardness}

For determination of hardness, a computerized texture measuring device (Texture Profile Analyser model TA-XT2i, Stable Micro Systems, Godalming, UK) fitted with a $25-\mathrm{kg}$ load cell was used. The product was subjected to a typical two-bite compression test using P-75 platen compression probe attached to the texture analyzer. The measurements were made at $\sim 15{ }^{\circ} \mathrm{C}$, a $50 \%$ compression level, and a test speed of $1.0 \mathrm{~mm} \cdot \mathrm{s}^{-1}$. Three replicates were analyzed for each sample (Bourne 2002).

\subsection{Meltability}

Meltability was determined by the method of Oberg et al. (1993). Ten-gram shredded cheese was filled into a Pyrex glass tube $(32 \mathrm{~mm} \times 250 \mathrm{~mm})$ and gently tapped with a spatula until each of the samples occupied a length of about $3.5 \mathrm{~cm}$. One end of the tubes was sealed with stoppers (silicon rubber) and the other with aluminum foil having a small hole to allow gas to escape. The tubes were tempered at $4{ }^{\circ} \mathrm{C}$ for $30 \mathrm{~min}$ in a vertical position (stoppered side down) and then placed horizontally in an oven at $100{ }^{\circ} \mathrm{C}$ for $60 \mathrm{~min}$. After cooling to room temperature, the length of melted cheese was recorded in centimeters.

\subsection{Stretchability}

Stretchability of cheese was measured on pizza by following the procedure described by Walsh et al. (1998). Shredded cheese $\left(0.25 \mathrm{~g} . \mathrm{cm}^{-2}\right)$ was evenly distributed on the pizza base that was pre-cut in two halves and was placed in the oven at $280{ }^{\circ} \mathrm{C}$ for $4 \mathrm{~min}$ and then evaluated for stretchability. One half of the pizza was clamped, and the unclamped section was manually pulled until the extended string joining both sections of pizza base completely broke. The stretch was recorded by measuring the distance $(\mathrm{cm})$ between the pizza halves.

\subsection{Experimental design and statistical analysis}

For PMC, a central composite rotatable design (CCRD) was employed using quadratic model to set up the experimental design. The numbers of design points were obtained using statistical software package Design Expert ${ }^{\circledR} 8.0$ (Stat-Ease, Inc., 2021 E. Hennepin Ave., Suite 480, Minneapolis, USA) based on the number of independent variables. The central values of the two factors, i.e., levels of $\% \mathrm{ES}$ and $\% \mathrm{KCl}$ in total common salt coded as X1 and X2, were decided to be 1.5 and $50 \%$, respectively. Their range and levels are given in Table 1 . Flavor $\left(\mathrm{Y}_{1}\right)$, body and texture $\left(\mathrm{Y}_{2}\right)$, color and appearance $\left(\mathrm{Y}_{3}\right)$, hardness $\left(\mathrm{Y}_{4}\right)$, meltability $\left(\mathrm{Y}_{5}\right)$, and stretchability $\left(\mathrm{Y}_{6}\right)$ were taken as the responses of the design of experiment. The center points for these designs were selected with ingredients at levels expected to yield satisfactory results. For each response, analysis of variance (ANOVA) was conducted to determine significant 
Table 1 Experimental ranges and levels of independent variables used in RSM in terms of actual and coded factors

\begin{tabular}{lllll}
\hline & Variables & -1 & 0 & 1 \\
\hline ES $(\%)$ & $\mathrm{X}_{1}$ & 1.0 & 1.5 & 2.0 \\
$\mathrm{KCl}(\%$ of total salt $)$ & $\mathrm{X}_{2}$ & 25 & 50 & 75 \\
\hline
\end{tabular}

${ }^{\text {a }}$ Total salt was added at the rate of $1 \%$

differences among various ingredient combinations using the statistical software package. Sensory scores of flavor; body and texture; and color and appearance were maximized; hardness, meltability, and stretchability were kept in range to obtain the most desirable optimized formulation of ingredients.

As PMC involved two independent variables, there are eight non-central points and five central points (Table 2). It was assumed that the response $(y)$ is a function of the experimental factors $(\mathrm{X} 1, \mathrm{X} 2)$ or $y=\mathrm{f}(\mathrm{X} 1, \mathrm{X} 2)$. The basic model equation used to fit the data was:

$$
Y=\beta_{0}+\beta_{1} X_{1}+\beta_{2} X_{2}+\beta_{11} X_{1}^{2}+\beta_{22} X^{2}{ }_{2}+\beta_{12} X_{1} X_{2}
$$

where $Y=$ responses; $\beta_{0}=$ constant; $\beta_{1}, \beta_{2}=$ linear regression coefficients; $\beta_{11}, \beta_{22}=$ quadratic regression coefficients; $\beta_{12}=$ interaction regression coefficients; and $X_{1}, X_{2}=$ variables. The effect of variables at the linear, quadratic, and interactive levels on individual response was described using significance at $5 \%$ levels of confidence.

Table 2 Experimental design depicting levels of emulsifying salt and potassium chloride and responses for each run

\begin{tabular}{lllrlrlrl}
\hline $\begin{array}{l}\text { Std. } \\
\text { run }^{\mathrm{a}}\end{array}$ & $\mathrm{X}_{1}(\%)$ & $\mathrm{X}_{2}(\%)$ & $\mathrm{Y}_{1}\left(50^{\mathrm{b}}\right)$ & $\mathrm{Y}_{2}\left(30^{\mathrm{b}}\right)$ & \multicolumn{1}{l}{$\mathrm{Y}_{3}\left(10^{\mathrm{b}}\right)$} & \multicolumn{1}{l}{$\mathrm{Y}_{4}(\mathrm{~N})$} & \multicolumn{1}{c}{$\mathrm{Y}_{5}(\mathrm{~cm})$} & $\mathrm{Y}_{6}(\mathrm{~cm})$ \\
\hline 1 & 1.00 & 25.00 & $42.1 \pm 1.510$ & $26.4 \pm 0.900$ & $8.5 \pm 0.436$ & $12.6 \pm 0.458$ & $12.6 \pm 0.436$ & $19.5 \pm 0.332$ \\
2 & 2.00 & 25.00 & $41 \pm 1.732$ & $26.8 \pm 1.229$ & $8.4 \pm 0.436$ & $15 \pm 0.624$ & $15 \pm 0.409$ & $22.1 \pm 0.269$ \\
3 & 1.00 & 75.00 & $30 \pm 1.670$ & $20.2 \pm 1.353$ & $8.1 \pm 0.624$ & $12.1 \pm 0.200$ & $12.1 \pm 0.567$ & $19.2 \pm 0.665$ \\
4 & 2.00 & 75.00 & $31.25 \pm 1.540$ & $24 \pm 0.529$ & $8.5 \pm 0.608$ & $15.1 \pm 0.150$ & $15.1 \pm 0.278$ & $22.7 \pm 0.255$ \\
5 & 0.79 & 50.00 & $35.5 \pm 0.954$ & $22.2 \pm 1.212$ & $8 \pm 0.265$ & $11.4 \pm 0.173$ & $11.4 \pm 0.056$ & $18.7 \pm 0.408$ \\
6 & 2.21 & 50.00 & $36.25 \pm 0.770$ & $25.1 \pm 0.624$ & $9.4 \pm 0.265$ & $15.2 \pm 0.087$ & $15.2 \pm 0.467$ & $21.9 \pm 0.361$ \\
7 & 1.50 & 14.64 & $44.12 \pm 1.555$ & $27.4 \pm 0.781$ & $8.2 \pm 0.100$ & $14.6 \pm 0.458$ & $14.6 \pm 0.332$ & $20.4 \pm 0.233$ \\
8 & 1.50 & 85.36 & $26.54 \pm 1.611$ & $22.3 \pm 0.608$ & $8.3 \pm 0.100$ & $14.5 \pm 0.265$ & $14.5 \pm 0.122$ & $20.8 \pm 0.569$ \\
9 & 1.50 & 50.00 & $37 \pm 1.852$ & $22.9 \pm 1.5539$ & $9.3 \pm 0.400$ & $14.3 \pm 0.218$ & $14.3 \pm 0.471$ & $20.8 \pm 0.249$ \\
10 & 1.50 & 50.00 & $38 \pm 1.808$ & $23.8 \pm 0.265$ & $8.8 \pm 0.300$ & $14.1 \pm 0.167$ & $14.1 \pm 0.141$ & $20.5 \pm 0.4447$ \\
11 & 1.50 & 50.00 & $37.25 \pm 1.106$ & $23.1 \pm 0.500$ & $9 \pm 0.173$ & $14.5 \pm 0.342$ & $14.5 \pm 0.115$ & $20.3 \pm 0.693$ \\
12 & 1.50 & 50.00 & $39 \pm 1.418$ & $23.2 \pm 0.361$ & $8.6 \pm 0.361$ & $14.7 \pm 0.346$ & $14.7 \pm 0.767$ & $20.7 \pm 0.671$ \\
13 & 1.50 & 50.00 & $35 \pm 0.866$ & $23.4 \pm 0800$ & $8.1 \pm 0.520$ & $14 \pm 0.350$ & $14 \pm 0.901$ & $20.6 \pm 0.801$ \\
\hline
\end{tabular}

$\mathrm{X}_{1}=\% \mathrm{ES}\left(\mathrm{g} / 100 \mathrm{~g}\right.$ PMC), $\mathrm{X}_{2}=\% \mathrm{KCl}(\%$ of total salt $), \mathrm{Y}_{1}=$ flavor, $\mathrm{Y}_{2}=$ body and texture, $\mathrm{Y}_{3}=$ color and appearance, $\mathrm{Y}_{4}=$ hardness, $\mathrm{Y}_{5}=$ meltability, and $\mathrm{Y}_{6}=$ stretchability. Values are mean \pm standard deviation

${ }^{\mathrm{a}}$ Serial number of experiment as given by RSM;

${ }^{\mathrm{b}}$ Maximum scores of responses 
The optimization was carried out by the desirability function. The optimized solution provided by the software was further validated by manufacturing PMC using optimized levels of $\mathrm{ES}\left(\mathrm{X}_{1}\right)$ and $\mathrm{KCl}\left(\mathrm{X}_{2}\right)$. Mean values of three replicates were used for comparison. Student's $t$ test (IBM SPSS Statistics version 20.0.) was used to check significant difference between actual and predicted values.

\section{Results}

The quadratic model was found suitable for flavor $(p<0.0001)$, body and texture $(p=<0.0001)$, hardness $(p=0.0024)$, meltability $(p<0.0001)$, and stretchability $(p<0.0001)$ response in PMC. $R^{2}$ of the model for various responses ranged from 90 to $96 \%$, and based on these values, it can be said that independent variables are able to explain much of the variation in responses (Table 3). Color and appearance was insignificant $(p=0.31)$ after conducting the analysis of data, concluding that no significant effect of amount of ES and $\% \mathrm{KCl}$ of total salt was obtained on color and appearance score of PMC. The $p$ value indicates the $p>\mathrm{F}$ value which should be less than 0.05 for model to be significant; otherwise, the model cannot be used for further routing or prediction. All the quadratic models were fitted using Design Expert 8.0 software. The effects of change in the levels of selected ingredients on the response parameters, i.e., flavor, body and texture, hardness, stretchability, and meltability values, are represented in Fig. 1.

\subsection{Flavor}

As represented in Table 2, maximum response for flavor score (44.12) was obtained with $1.50 \% \mathrm{ES}$ and $14.64 \% \mathrm{KCl}$ of total salt. Minimum response for flavor score (30) was obtained with $1.00 \% \mathrm{ES}$ and $75 \% \mathrm{KCl}$. $\mathrm{KCl}$ content $\left(\mathrm{X}_{2}\right)$ significantly decreased the flavor score of PMC once the linear regression coefficient was negative and significant $(p<0.05)$. Effect of increasing level of ES on flavor of PMC was found insignificant $(p>0.05)$. The coefficient of determination $\left(R^{2}\right)$ was obtained to be 0.9641 for flavor (Table 3 ). The following Eq. (1) was obtained from the analysis after eliminating insignificant terms:

$$
\text { Flavor }=+37.25-5.84 * \mathrm{X}_{2}
$$

Table 3 ANOVA and quadratic model statistics for PMC

\begin{tabular}{lllllll}
\hline \multirow{2}{*}{ S. No. } & Term & \multicolumn{2}{l}{ Response } & & \\
\cline { 3 - 7 } & & Flavor & Body and texture & Hardness & Meltability & Stretchability \\
\hline 2 & F value & 37.57 & 77.20 & 12.26 & 54.35 & 24.55 \\
3 & $p>\mathrm{F}$ & $<0.0001$ & $<0.0001$ & 0.0024 & $<0.0001$ & 0.0003 \\
4 & Mean & 36.39 & 23.91 & 13.47 & 14.01 & 20.63 \\
5 & Standard deviation (SD) & 1.22 & 0.36 & 0.31 & 0.25 & 0.34 \\
7 & $R^{2}$ & 0.9641 & 0.9822 & 0.8975 & 0.9749 & 0.9461 \\
10 & Adequate precision & 19.889 & 30.490 & 11.337 & 23.303 & 16.078 \\
\hline
\end{tabular}



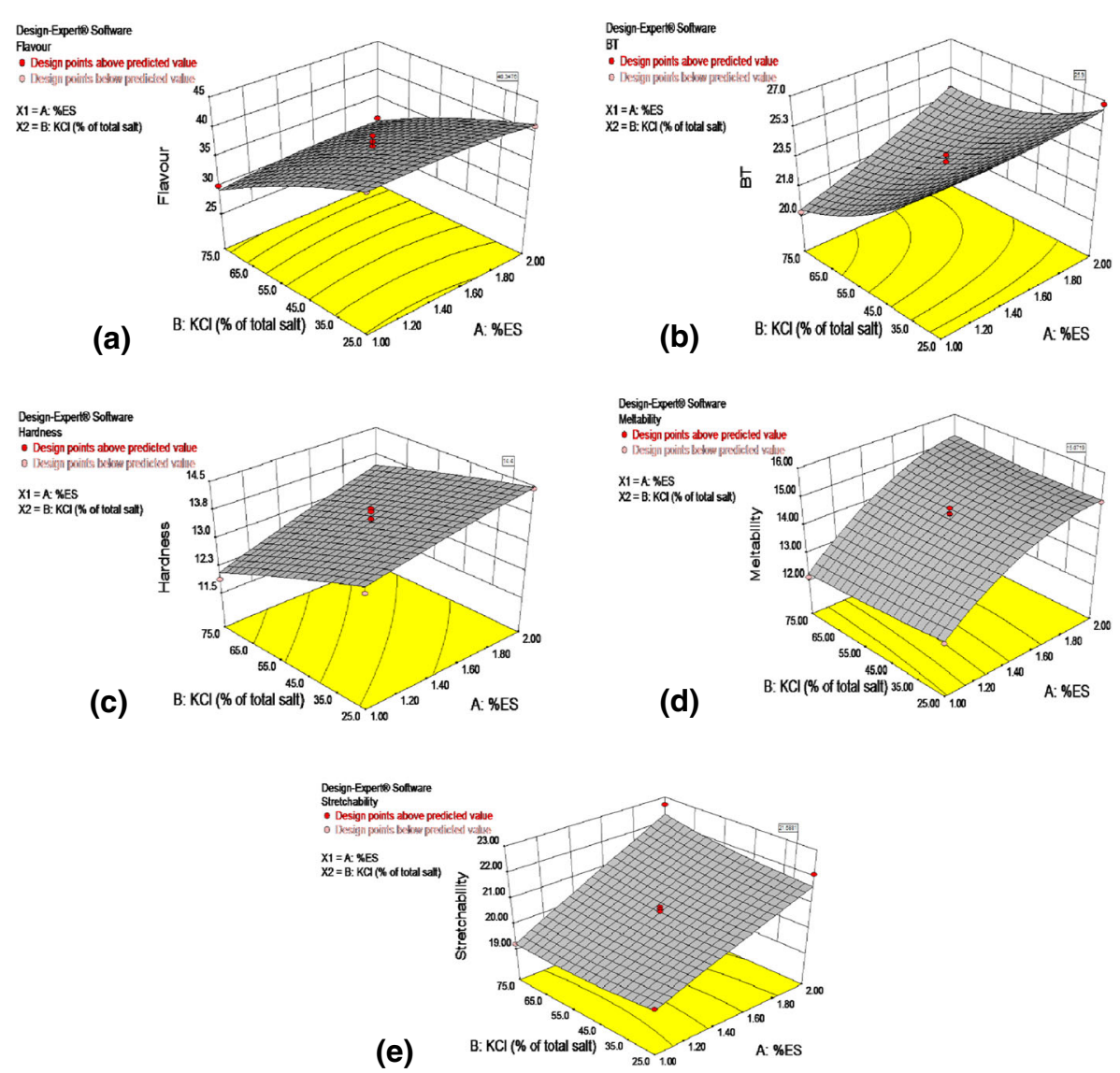

Fig. $13 \mathrm{D}$ plots depicting effect of $\mathbf{a} \% \mathrm{KCl}(B)$ on flavor score, $\mathbf{b} \% \mathrm{ES}(A)$ and $\% \mathrm{KCl}(B)$ on body and texture score, $\mathbf{c} \% \mathrm{ES}(A)$ and $\% \mathrm{KCl}(B)$ on hardness, d $\% \mathrm{ES}(A)$ on meltability, and e $\% \mathrm{ES}(A)$ on stretchability of $\mathrm{PMC}$ ( $E S$ emulsifying salt, $\mathrm{KCl}$ potassium chloride, $\mathrm{PMC}$ processed Mozzarella cheese)

\subsection{Body and texture}

ES content of $1.50 \%$ and $14.64 \% \mathrm{KCl}$ of total salt returned maximum response while a minimum response for body and texture (20.2) was obtained with $1.00 \%$ ES and $75 \%$ $\mathrm{KCl}$ of total salt. The model suggested significant effect of $\% \mathrm{ES}$ and $\% \mathrm{KCl}$ on body and texture $(p<0.05)$ with 0.9822 coefficient of determination. Interaction regression coefficient of $\% \mathrm{ES}$ and $\% \mathrm{KCl}$ was also found significant $(p<0.05)$. The regression equation obtained for predicting the effect of variables on body and texture scores is as follows:

$$
\mathrm{BT}=+23.28+1.04 * \mathrm{X}_{1}-2.03 * \mathrm{X}_{2}+0.85 * \mathrm{X}_{1} * \mathrm{X}_{2}+0.81 * \mathrm{X}_{2}^{2}
$$

\subsection{Hardness}

Instrument hardness value was found to be maximum $(14.60 \mathrm{~N})$ at $1.50 \% \mathrm{ES}$ and $14.64 \% \mathrm{KCl}$ and minimum $(11.4 \mathrm{~N})$ at $0.79 \% \mathrm{ES}$ and $50 \% \mathrm{KCl}$. Hardness of PMC was 
found to be significantly affected by ES levels and $\% \mathrm{KCl}$ used $(p<0.05)$. ES content $\left(\mathrm{X}_{1}\right)$ significantly increased and $\mathrm{KCl}$ levels significantly decreased the hardness value of PMC as the linear regression coefficient was positive and negative, respectively, and was significant $(p<0.05)$. The coefficient of determination $\left(R^{2}\right)$ was obtained to be 0.8975 for hardness (Table 3 ). From analysis of data, the following regression equation with significant terms was obtained:

$$
\text { Hardness }=+13.52+0.53 * \mathrm{X}_{1}-0.65 * \mathrm{X}_{2}
$$

\subsection{Meltability}

Maximum response for meltability $(15.2 \mathrm{~cm}$ ) was obtained with $2.21 \%$ ES and $50 \%$ $\mathrm{KCl}$ while $0.79 \% \mathrm{ES}$ and $50 \% \mathrm{KCl}$ returned minimum response $(11.4 \mathrm{~cm})$. Increasing ES content significantly $(p<0.05)$ increased the meltability of PMC. The coefficient of determination $\left(R^{2}\right)$ was obtained to be 0.9749 for meltability (Table 3 ). The following Eq. (4) was obtained after eliminating insignificant terms:

$$
\text { Meltability }=+14.32+1.35 * \mathrm{X}_{1}-0.57 * \mathrm{X}_{1}^{2}
$$

\subsection{Stretchability}

Analysis of stretchability scores suggested maximum $(22.7 \mathrm{~cm})$ response with $2 \%$ ES and $75 \% \mathrm{KCl}$ of total salt while $0.79 \% \mathrm{ES}$ and $50 \% \mathrm{KCl}$ returned minimum response $(18.7 \mathrm{~cm})$. Increasing the ES content $\left(\mathrm{X}_{1}\right)$ significantly increased stretchability of PMC once the linear regression coefficient was positive and significant $(p<0.05)$. Content of $\mathrm{KCl}$ had insignificant effect $(p>0.05)$ on stretchability of PMC. The coefficient of determination $\left(R^{2}\right)$ was obtained to be 0.9461 for stretchability (Table 3 ). The model can be represented by the following Eq. (5) considering only significant terms:

$$
\text { Stretchability }=+20.58+1.33 * \mathrm{X}_{1}
$$

Further, the optimization of variable levels was achieved by desirable maximization of the necessary response along the fitted quadratic models by numerical optimization procedure of Design Expert 8.0 software (Fig. 2). Final result for this optimization suggested that the PMC containing $2 \% \mathrm{ES}$ and $30.96 \% \mathrm{KCl}$ of total salt achieved the best solution for this combination of variables. The composition of final optimized low-sodium PMC and its comparison with full-sodium or regular PMC is as shown in Table 4. This new ingredient mixture was submitted to the same experimental analytical procedures applied as those from the beginning of this study. Actual and predicted values were compared using Student's $t$ test, and the $p$ value $(<0.05)$ suggested no significant difference between the two. Since, the fitted models are best suitable for predicting the responses of the study, the proposed model could be used to have an idea about the response value (Table 5).

\section{Discussion}

Substitution of $\mathrm{NaCl}$ by $\mathrm{KCl}$ to level of $75 \%$ in PMC adversely impacted the flavor score. This tendency could be observed due to less saltiness perception of $\mathrm{KCl}$ as 


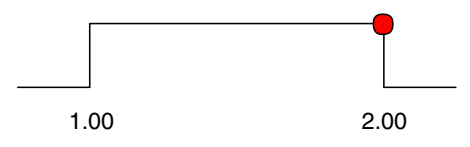

$\mathrm{A}:$ Blend $=2.00$

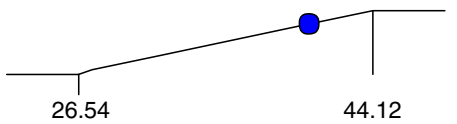

Flavour $=40.3483$

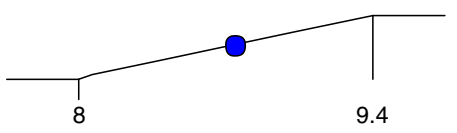

$\mathrm{CA}=8.74744$

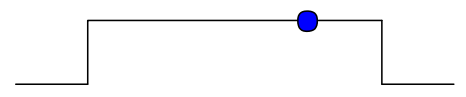

18.7

Stretchability $=21.6881$

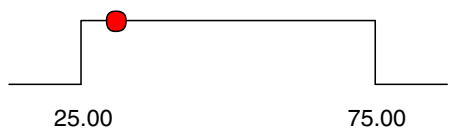

$\mathrm{B}:$ Parts of $\mathrm{KCl}=30.96$

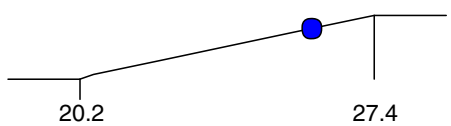

$\mathrm{BT}=25.8937$

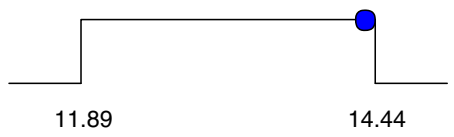

Hardness $=14.355$

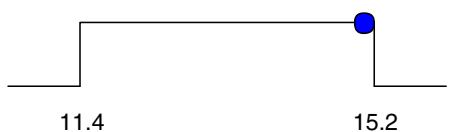

Meltability $=15.0719$

\section{Desirability $=0.692$}

Fig. 2 Graphical representation of optimized levels of independent variables of processed Mozzarella cheese (PMC) with desirability

compared to $\mathrm{NaCl}$. Cations such as potassium, magnesium, and calcium give sourness and less saltiness compared to sodium, which offers what is really recognized as pure salty taste (Kilcast and Ridder 2007). In the present study, with increasing levels of $\mathrm{KCl}$, flavor score of PMC was shown to decrease with enhanced bitterness perception. Similar findings for imitation cheese (El-Bakry et al. 2011) and process cheese (Zehren and Nusbaum 2000) were proven to cause bitter taste perception on more than $50 \%$ substitution of $\mathrm{NaCl}$ with $\mathrm{KCl}$. Utilization of potassium-based emulsifying salts in preparation of processed cheese was also encountered to affect the flavor such as a decrease in the overall saltiness and development of bitter and chemical-metallic offflavors (Gupta et al. 1984; Karahadian and Lindsay 1984; Henson 1997). Textural aspects perceived in the mouth play a primitive role in determining overall quality of products. In the present study, ES content affected the body and texture of PMC significantly which resulted in appropriate hard texture PMC. Thus, high scores for 
Table 4 Proximate composition of full- and low-sodium PMC

Values are mean \pm standard deviation

\begin{tabular}{lcc}
\hline Composition & Full-sodium PMC & Low-sodium PMC \\
\hline Moisture (\%) & $46.95 \pm 1.131$ & $46.18 \pm 0.235$ \\
Fat (\%) & $20.72 \pm 0.488$ & $20.27 \pm 0.731$ \\
Protein (\%) & $26.02 \pm 0.970$ & $27.74 \pm 3.883$ \\
Ash (\%) & $3.57 \pm 0.085$ & $3.82 \pm 0.450$ \\
Salt (\%) & $1.03 \pm 0.056$ & $1.07 \pm 0.082$ \\
Na (mg/100 g) & $905.0 \pm 10.985$ & $260.0 \pm 3.559$ \\
K (mg/100 g) & $38.00 \pm 1.732$ & $633.0 \pm 5.292$ \\
\hline
\end{tabular}

body and texture were obtained on increasing the content of ES in formulation. Increasing $\mathrm{KCl}$ content had the inverse role and the cheese was softer with pasty body. Replacement of $\mathrm{NaCl}$ with $\mathrm{KCl}$ must be carefully studied as at high concentrations $(>1 \%), \mathrm{KCl}$ tends to decrease cheese firmness (Cruz et al. 2011).

Trend of increasing hardness of PMC on ES addition can be attributed to the enhanced insoluble casein dispersion, calcium chelation, and ion exchange. Similar results were reported by the study of Chen and Liu (2012) in which effect of different types of ES was investigated on hardness of processed cheese made from Mozzarella. Similarly, Shirashoji et al. (2010) investigated the effect of varying concentration $(0.25-2.75 \%)$ of sodium hexa metaphosphate on hardness of pasteurized process cheese, wherein cheese with higher ES administered to have greater hardness. ES concentration influences both the breakage of linkages between casein and type and number of interaction or linkage formed during cooling-gelling phase (Shirashoji et al. 2010). ES results in re-association of casein molecules and also the formation of ES-Ca complexes after cooling of processed cheese which aid in cross-linking casein in gelling system (Shirashoji et al. 2010). Casein dispersion ability of ES is pH dependent which is low near pH 5.0 (Dimitreli et al. 2005). PMC made during the study had pH of 5.2 near which ES should be efficient in causing casein dispersion. The greater the degree of casein dispersion, the firmer and more cross-linked is the final process cheese made. Similar results were given during trisodium citrate addition to process cheese (Shirashoji et al. 2006) and sodium hexametaphosphate addition to pasteurized process cheese (Shirashoji et al. 2010) for which the authors proposed that ES addition also improves fat emulsification indirectly by dispersing insoluble casein. Dispersed casein acts as an emulsifier which further emulsifies the liquid fat released during heating and shearing of natural cheese. On substitution of $\mathrm{NaCl}$ with $\mathrm{KCl}$, hardness of cheese decreased significantly which is in accordance with the results of Ayyash et al. (2011)

Table 5 Predicted response versus actual response

\begin{tabular}{|c|c|c|c|c|c|}
\hline \multirow[t]{2}{*}{ Values } & \multicolumn{5}{|c|}{ Response } \\
\hline & Flavor & Body and texture & Hardness & Meltability & Stretchability \\
\hline Predicted & 40.35 & 25.90 & 14.40 & 15.10 & 21.69 \\
\hline Actual & 40.60 & 25.42 & 14.35 & 15.03 & 21.73 \\
\hline
\end{tabular}


who studied the effect of $\mathrm{NaCl}$ substitution with $\mathrm{KCl}$ on hardness of Halloumi cheese. On zero day storage, cheese samples were found to have decreasing trend of hardness with increasing $\mathrm{KCl}$ content $(3 \mathrm{NaCl}: 1 \mathrm{KCl}>1 \mathrm{NaCl}: 1 \mathrm{KCl}>1 \mathrm{NaCl}: 3 \mathrm{KCl})$.

Meltability and stretchability are important functional properties of Mozzarella cheese which determine its suitability to be used as an ingredient in pizza making. Interactions between casein molecules results in melting and stretching properties of cheese (Lucey et al. 2003). With decreasing casein-casein interaction, meltability of cheese increases. Melting can be defined as the ability of a cheese to flow on heating (Lucey et al. 2003). In our study, meltability of PMC was significantly increased with addition of ES. These results suggested that ES used in this study resulted in chelation of $\mathrm{Ca}^{+}$by dissolving some colloidal calcium phosphate (CCP), which later decreased the casein-casein interactions and increased meltability. Reduced attractive interactions between casein micelles by the reduction in the number of CCP cross-links and an increase in electrostatic repulsion between them by exposure of the negative charges of phosphoserine residues possibly resulted in increased meltability (Lucey et al. 2003). This mechanism has relevance up to ES levels of $2 \%$ above which different pathways may take place (Brickley et al. 2008). According to the study by Brickley et al. (2008), non-fat process cheese manufactured with varying content and type of ES (trisodium citrate, disodium phosphate, and trisodium phosphate) was found to have increasing meltability of up to $2 \%$ ES which is similar to the content of ES used in present study.

Stretch is the ability of the casein network to continuously maintain its integrity without breaking when uninterrupted stress is applied to the cheese. Casein molecules must have a capability to interact with each other for good stretch; consequently, they should release stress which is applied and become pliable, i.e., should not break and maintain adequate contact in between (Lucey et al. 2003). It is known that for good stretching properties, relatively high concentrations of intact casein and critical concentrations of $\mathrm{Ca}$ and $\mathrm{P}$ are required (Lucey and Fox 1993). The study suggested increased stretchability with increasing level of ES of up to $2 \%$; however, further increase in the ES decreased stretchability significantly. The results corroborate the findings of Mizuno and Lucey (2005) which reported the increase in stretchability of pasta filata cheese on addition of ES of up to $1 \%$ above which casein-casein interactions were weakened. Validation of RSM model using Student's $t$ test suggested that the model can be successfully used to optimize the level of salt replacer and emulsifying salt. Further, regression equations generated by RSM can also be used effectively to predict the effect of alteration in the levels of $\mathrm{KCl}$ and potassium-based emulsifying salt on various sensory and instrumental responses.

\section{Conclusion}

Sodium in processed Mozzarella cheese was successfully reduced using a combination of $\mathrm{KCl}$ and potassium-based emulsifying salts. Desired or optimum level of these ingredients was obtained by using RSM, which returned $2 \%$ of emulsifying salts and $30.96 \% \mathrm{KCl}$ of total salt with a desirability of 0.692 . The flavor, body and texture, color and appearance, hardness, meltability, and stretchability of optimized levels of ES and $\mathrm{KCl}$ were predicted to be $40.34,25.89,8.74,14.35 \mathrm{~N}, 15.07 \mathrm{~cm}$, and $21.68 \mathrm{~cm}$, respectively. The results of RSM were validated by comparing actual and predicted 
values of responses which returned non-significant difference. The study suggested the successful use of potassium-based emulsifying salts and $\mathrm{KCl}$ for reducing sodium in processed Mozzarella cheese up to approximately $71 \%$ without jeopardizing its sensory, textural, and functional properties.

Acknowledgments Thankful acknowledgement is to the Director, National Dairy Research Institute, for providing economic assistance in the form of Junior Research Fellowship (Post Graduate Studies) constituted by Indian Council of Agricultural Research, Pusa, New Delhi, and other infrastructural amenities for conducting the presented research work.

Conflict of interest Ganesh B. Chavhan, S.K. Kanawjia, Yogesh Khetra, and Ritika Puri have no conflict of interest.

\section{References}

Aly ME (1995) An attempt for producing low-sodium Feta-type cheese. Food Chem 52:295-299

AOAC (1990) Official methods of analysis Washington. Association of Official Analytical Chemists, DC

AOAC (1992) Official methods of analysis Washington. Association of Official Analytical Chemists, DC

Ayyash MM, Shah NP (2010) Effect of partial substitution of $\mathrm{NaCl}$ with $\mathrm{KCl}$ on Halloumi cheese during storage: chemical composition, lactic bacterial count, and organic acids production. J Food Sci 75:C525-C529

Ayyash MM, Sherkat F, Francis P, Williams RPW, Shah NP (2011) The effect of sodium chloride substitution with potassium chloride on texture profile and microstructure of Halloumi cheese. J Dairy Sci 94:37-42

Bourne M (2002) Food texture and viscosity: concept and measurement. Academic Press, New York

Brickley CA, Govindasamy-Lucey S, Jaeggi JJ, Johnson ME, McSweeney PLH, Lucey JA (2008) Influence of emulsifying salts on the textural properties of nonfat process cheese made from direct acid cheese bases. J Dairy Sci 91:39-48

Chen L, Liu H (2012) Effect of emulsifying salts on the physicochemical properties of processed cheese made from Mozzarella. J Dairy Sci 95:4823-4830

Cruz AG, Faria JA, Pollonio MA, Bolini H, Celeghini R, Granato D, Shah NP (2011) Cheeses with reduced sodium content: effects on functionality, public health benefits and sensory properties. Trends Food Sci Tech 22:276-291

Cunha CR, Viotto WH (2010) Casein peptization, functional properties, and sensory acceptance of processed cheese spreads made with different emulsifying salts. J Food Sci 75:113-120

Dimitreli G, Thomareis AS, Smith PG (2005) Effect of emulsifying salts on casein peptization and apparent viscosity of processed cheese. Intl J Food Engg 1(4)

El-Bakry M, Beninati F, Duggan E, O’Riordan ED, O’Sullivan M (2011) Reducing salt in imitation cheese: effects on manufacture and functional properties. Food Res Intl 44:589-596

Gillette M (1985) Flavor effects of sodium chloride. Food Tech, USA

Guinee TP, Carić M, Kalab M (2004) Pasteurized processed cheese and substitute/imitation cheese products. In: Fox PF (ed.) Cheese: chemistry, physics and microbiology 2:349-394

Guinee TP, O’ Kennedy BT (2007) Reducing salt in cheese and dairy spreads. In: Kilcast D and Angus F (ed.) Reducing salt in foods: Practical strategies, Wood head publishing Ltd, CRC Press

Gupta SK, Karahadian C, Lindsay RC (1984) Effect of emulsifier salts on textural and flavor properties of processed cheeses. J Dairy Sci 67:764-778

Henson LS, inventor; FMC Corporation, assignee (1997) Reduced sodium content process cheese and method for making it. U.S. patent 5871797A1

Hoffmann W, Gärtner J, Lück K, Johannsen N, Maurer A (2012) Effect of emulsifying salts containing potassium on the quality of block-type processed cheese. Int Dairy J 25:66-72

ISI (1981) ISI handbook of food analysis. SP-18 (Part XI) Dairy Products. Bureau of Indian Standards, New Delhi

Jensen LA, Johnson ME, Olson NF (1987) Use of glucono-delta-lactone as an acidulant for low moisture part skim mozzarella cheese produced from ultrafiltered milk. J Dairy Sci 70:66-66

Johnson ME, Kapoor R, McMahon DJ, McCoy DR, Narasimmon RG (2009) Reduction of sodium and fat levels in natural and processed cheeses: scientific and technological aspects. Compr Rev Food Sci F 8: $252-268$

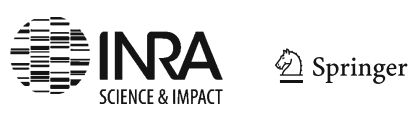


Karahadian C, Lindsay RC (1984) Flavor and textural properties of reduced-sodium process American cheeses. J Dairy Sci 67:1892-1904

Katsiari MC, Voutsinas LP, Alichanidis E, Roussis IG (1998) Manufacture of Kefalograviera cheese with less sodium by partial replacement of $\mathrm{NaCl}$ with $\mathrm{KCl}$. Food Chem 61:63-70

Katsiari MC, Voutsinas LP, Kondyli E (2002) Improvement of sensory quality of low-fat Kefalograviera-type cheese with commercial adjunct cultures. Int Dairy J 12:757-764

Kilcast D, Ridder CD (2007) Sensory issues in reducing salt in food products. In: Kilcast D, Angus F (ed.) Reducing salt in foods: Practical strategies. Wood head publishing Ltd, CRC Press

Lucey JA, Fox PF (1993) Importance of calcium and phosphate in cheese manufacture: a review. J Dairy Sci $76: 1714-1724$

Lucey JA, Johnson ME, Horne DS (2003) Invited review: perspectives on the basis of the rheology and texture properties of cheese. J Dairy Sci 86:2725-2743

Mizuno R, Lucey JA (2005) Effects of two types of emulsifying salts on the functionality of nonfat pasta filata cheese. J Dairy Sci 88:3411-3425

Oberg CJ, McManus WR, McMahon PJ (1993) Microstructure of Mozzarella cheese during manufacturing. Food Struct 12:251-258

Reddy KA, Marth EH (1994) Sensory evaluation of Cheddar cheese made with sodium chloride or mixtures of sodium and potassium chloride. J Sensory Stud 9:187-204

Shirashoji N, Jaeggi JJ, Lucey JA (2006) Effect of trisodium citrate concentration and cooking time on the physicochemical properties of pasteurized process cheese. J Dairy Sci 89:15-28

Shirashoji N, Jaeggi JJ, Lucey JA (2010) Effect of sodium hexametaphosphate concentration and cooking time on the physicochemical properties of pasteurized process cheese. J Dairy Sci 93:2827-2837

Tuomilehto J, Jousilahti P, Rastenyte D, Moltchanov V, Tanskanen A, Pietinen P, Nissinen A (2001) Urinary sodium excretion and cardiovascular mortality in Finland: a prospective study. Lancet 357:848-851

Walsh CD, Guinee TP, Harrington D, Mehra R, Murphy JM, Fitzgerald RJ (1998) Cheese making, compositional and functional characteristics of low moisture part-skim mozzarella cheese from bovine milks containing k-casein AA, AB or BB genetic variants. J Dairy Res 65:307-315

WHO (2012) Guideline: sodium intake for adults and children. World Health Organization (WHO), Geneva World Health Organization \& International Society of Hypertension Writing Group (2003) 2003 World Health Organization (WHO)/International Society of Hypertension (ISH) statement on management of hypertension. J Hypertens 21:1983-1992

Zehren VL, Nusbaum DD (1992) The cheese making process. In: Process cheese. Green Bay, WI: D. Cooley \& Co Zehren VL, Nusbaum DD (2000) Processed cheese, 2nd edn. Cheese Reporter Publishing Co. Inc., Madison 